\title{
Clarification of Industrial Mining Wastewater Using Electrocoagulation
}

\author{
Soraya Touahria ${ }^{1, *}$, Sabir Hazourli ${ }^{1}$, Khedidja Touahria ${ }^{2}$, Amina Eulmi $^{1}$, Adel Aitbara ${ }^{1}$ \\ ${ }^{1}$ Laboratory of Water Treatment and Valorization of Industrial Wastes, Chemistry Department, \\ Faculty of Sciences, Badji-Mokhtar University, Bp12, 23000, Annaba, Algeria \\ ${ }^{2}$ Chemistry Department, Faculty of exact sciences and natural sciences and life, Tebessa University, \\ 12000, Tebessa, Algeria \\ *E-mail: soraya.chimie@yahoo.fr
}

doi: $10.20964 / 2016.07 .51$

Received: 13 March 2016 / Accepted: 17 May 2016 / Published: 4 June 2016

The treatment of industrial mining wastewater (IMWW) by electrocoagulation (EC) using aluminum electrodes has been conducted with real wastewater taken from a mining industry. For reuse this water, several experiments were carried out in order to optimize the conditions of technique's applicability. The results showed that turbidity (560 NTU) was removed reaches $99 \%$ at current density $10 \mathrm{~mA} / \mathrm{cm}^{2}$, free $\mathrm{pH} 7.2$ and temperature of wastewater $\sim 20^{\circ} \mathrm{C}$. The clarification of IMWW is very quick (EC time $<10 \mathrm{~min}$ ) and adequately described by pseudo-second-order kinetics model. Moreover under optimal conditions, all parameters of pollution measured after EC are below the standard norms of industrial discharges. The EC process can be applied 10 times without loss of efficiency, it led to a minimal volume of sludge $\left(65-75 \mathrm{~cm}^{3} / \mathrm{L}\right)$, and a low cost treated effluent $\sim 6 \$ \mathrm{~m}^{3}$.

Keywords: Electrocoagulation, mining, operating cost, turbidity, Wastewater treatment.

\section{$\underline{\text { FULL TEXT }}$}

(C) 2016 The Authors. Published by ESG (www.electrochemsci.org). This article is an open access article distributed under the terms and conditions of the Creative Commons Attribution license (http://creativecommons.org/licenses/by/4.0/). 